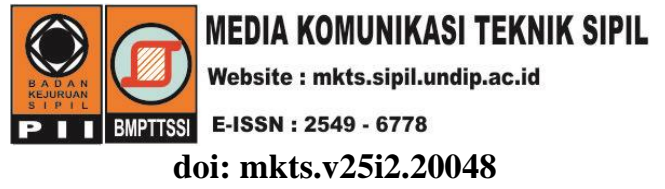

\title{
Pengaruh Pembebasan Tanah terhadap Keterlambatan Proyek Pembangunan Jalan Tol Studi Kasus: Jalan Tol Cinere-Jagorawi Seksi II B
}

\author{
* Ovie Lativatul Khofiyah, Ida Ayu Ari Angreni \\ Fakultas Teknik Sipil dan Perencanaan, Universitas Gunadarma, Jakarta \\ *)oviethestary@ rocketmail.com
}

Received: 28 Agustus 2018 Revised: 25 November 2019 Accepted: 2 Desember 2019

\begin{abstract}
Land acquisition for Cinere-Jagorawi toll road section II B should be completed in 2010, but till now (status 15 June 2017) from the need of $17.6 \mathrm{HA}$, only 16,1353 HA or 91,677\% are free. Progress of land acquisition resulted in progress deviation of construction. This study aims to analyze the effect of land acquisition which is resulted in the performance of Cinere-Jagorawi toll road project of section II B late. Data was collected by spreading questionnaires related to the stages and technical implementation of land acquisition, internal factors and external factors inhibiting land acquisition to respondents from Ministry of PUPR, BPN Depok, and community. The result of analysis using regression analysis obtained X15, X17, and X33 as the best variable. The conclusion is, X15 (Funding for public procurement is sourced from the State Budget) with a coefficient of 0.34 as the first influential factor, X17 (Data collection of land status and its document) with the coefficient of 0.257 as the second influential factor, and X33 (Limitations of time for BPN in handling land procurement due to the amount of land to be acquired) with the coefficient of 0.146 as the third influential factor.
\end{abstract}

Keywords: Land acquisition, questionnaires, regression analysis, variable, influence

\begin{abstract}
Abstrak
Pembebasan tanah untuk jalan tol Cinere-Jagorawi seksi II B seharusnya selesai tahun 2010, tapi hingga saat ini (status 15 Juni 2017) dari kebutuhan 17,6 HA baru bebas 16,1353 HA atau 91,677\%. Progres pembebasan tanah tersebut mengakibatkan deviasi pada progres konstruksi. Penelitian ini bertujuan untuk menganalisis pengaruh pembebasan tanah yang mengakibatkan kinerja proyek pembangunan jalan tol Cinere-Jagorawi seksi II B terlambat. Pengambilan data dilakukan dengan penyebaran kuesioner terkait tahapan dan teknis pelaksanaan pengadaan tanah, faktor dalam dan faktor luar penghambat pembebasan tanah pada responden dari Kementerian PUPR, BPN Depok, serta masyarakat. Hasil analisis regresi menunjukkan diperoleh variabel terbaik yaitu Pendanaan pengadaan tanah untuk kepentingan umum bersumber dari Anggaran Pendapatan dan Belanja Negara (APBN), Pengumpulan data status tanah dan dokumennya, dan Keterbatasan waktu bagi BPN dalam menangani kegiatan pengadaan tanah karena banyaknya tanah yang harus dibebaskan. Kesimpulannya adalah Pendanaan pengadaan tanah untuk kepentingan umum bersumber dari APBN dengan koefisien 0,34 sebagai faktor yang paling berpengaruh pertama, Pengumpulan data status tanah dan dokumennya dengan koefisien 0,257 sebagai faktor yang paling berpengaruh kedua, dan Keterbatasan waktu bagi BPN dalam menangani kegiatan pengadaan tanah karena banyaknya tanah yang harus dibebaskan dengan koefisien 0,146 sebagai faktor yang paling berpengaruh ketiga.
\end{abstract}

Kata kunci: Pembebasan tanah, kuesioner, analisis regresi, variabel, pengaruh

\section{Pendahuluan}

Permasalahan pembangunan di Indonesia dibagi menjadi dua bagian besar yaitu masalah obyek pembangunan dan masalah subyek yang akan melakukan pembangunan. Permasalahan yang berasal dari subyek pembangunan yaitu dalam hal pengadaan lahan (Musra, 2014). 
Masalah pembebasan tanah sangat rawan dalam penanganannya, karena di dalamnya menyangkut hajat hidup orang banyak, apabila dilihat dari kebutuhan pemerintah akan tanah untuk keperluan pembangunan, dapatlah dimengerti bahwa tanah negara yang tersedia sangatlah terbatas, oleh karena itu satu-satunya cara yang dapat ditempuh adalah dengan membebaskan tanah milik masyarakat, baik yang telah di kuasai dengan hak berdasarkan Hukum Adat maupun hak-hak lainnya menurut UUPA (Marlijanto, 2010). Kebutuhan akan lahan infrastruktur tidak mungkin hanya didapatkan dari satu sumber kepemilikan (Listyaningsih \& Utomo, 2014).

Persoalan klasik pembangunan jalan tol di Indonesia antara lain biaya pengadaan tanah menjadi beban investor, waktu dan biaya pengadaan yang tidak pasti, waktu konsesi berkurang akibat lamanya proses pembebasan tanah sehingga menurunkan tingkat kelayakan finansial. Selain itu juga masalah pengadaan tanah karena faktor Panitia Pembebasan Tanah (P2T), sengketa tanah, aturan-aturan multi tafsir UndangUndang Pokok Agraria Nomor 5 Tahun 1960, proses pembebasan tanah melalui musyawarah dan kemampuan Badan Usaha Jalan Tol (BUJT) dalam penyediaan equitas. Dibandingkan negara-negara di Asia, Indonesia termasuk negara yang masih mengalami kesulitan terhadap pelaksanaan pembebasan lahan karena masalah hukum yang tidak tegas. Peliknya masalah proses pembebasan lahan mempengaruhi semua sumber daya yang ada (Hermawan et al. 2011).

Pada pembangunan jalan tol produktifitas pekerjaan sangat didominasi oleh ketersediaan lahan. Fenomena pembebasan lahan tidak semudah regulasinya (Hermawan et al. 2011). Kendala yang dialami pada proses pembebasan tanah bukan hanya mengenai besaran dari biaya tanah saja tetapi juga mengenai waktu pelaksanaannya (Dharmawan, 2012). Salah satu permasalahan yang dapat mempengaruhi kinerja proyek adalah masalah pembebasan tanah karena merupakan langkah awal pelaksanaan pengerjaan fisik lapangan (Mekanisari, 2009).

Masih adanya lahan yang belum bebas saat pelaksanaan pekerjaan masih berjalan merupakan salah satu respon risiko dominan yang berdampak terhadap waktu dan biaya (Santoso et al. 2017). Bahkan Jasa Marga yang merupakan investor terbesar di bidang penyediaan infrastruktur jalan tol menyebutkan bahwa risiko investasi jalan tol tertinggi adalah terletak pada tahapan pembebasan lahan dan kostruksi (Firmanto et al. 2010). Proses pembebasan tanah yang cukup memerlukan waktu sangat berpengaruh pada proses pengerjaan
(Kamaruzzaman, 2012). Kendala utama dalam kebutuhan infrastruktur untuk menopang pertumbuhan ekonomi adalah pengadaan tanah (Ade-Surya, 2011).

Kasus keterlambatan pembangunan jalan tol akibat pembebasan lahan terjadi pada proyek pembangunan jalan tol Pemalang-Batang. Perkembangan mengenai sulitnya pembebasan lahan mendorong dilakukannya kajian terhadap kelayakan pembangunan tol ruas Pemalang-Batang (Hasani et al. 2016). Permasalahan pengadaan tanah yang dilakukan dengan pembebasan tanah tersebut pada gilirannya secara signifikan berdampak pada pembiayaan pembangunan jalan, jadwal pekerjaan dan desain fisik jalan tol (Hutabarat, 2008).

Penelitian sebelumnya terkait pembebasan tanah menyebutkan bahwa faktor risiko dominan dalam pembebasan tanah Proyek Banjir Kanal Timur Jakarta adalah akibat warga yang menuntut uang ganti kerugian lebih tinggi dari harga NJOP serta adanya perbedaan harga tanah karena kedekatan dengan lokasi bisnis (Mekanisari, 2009). Penelitian tersebut menggunakan variabel faktor internal dan faktor eksternal. Faktor yang ditemukan dalam penelitian tersebut adalah warga yang menuntut uang ganti kerugian lebih tinggi dari harga NJOP dan adanya perbedaan harga tanah karena kedekatan dengan lokasi bisnis.

Penelitian ini penting karena proses pembebasan tanah berkaitan dengan produktivitas proyek yang menyebabkan konstruksi jalan tol belum bisa beroperasi. Penelitian ini menggunakan variabel faktor dalam, faktor luar, serta faktor tahapan dan teknis pelaksanaan pengadaan tanah. Faktor tahapan dan teknis pelaksanaan pengadaan tanah penting ditinjau karena berhubungan dengan faktor dalam dan faktor luar. Penggunaan input faktor tahapan dan teknis pelaksanaan pengadaan tanah inilah yang membedakan penelitian ini dengan penelitian sebelumnya.

Faktor tahapan dan teknis pelaksanaan pengadaan tanah berisi tahapan dan teknis pelaksanaan pengadaan tanah yang menghambat proses pembebasan tanah. Variabel-variabel dalam faktor ini disajikan dalam Tabel 1. Faktor Dalam berisi peranan instansi yang memerlukan tanah/ pelaksanaan pengadaan tanah yang menghambat proses pembebasan tanah. Variabel-variabel dalam faktor ini dapat dilihat dalam Tabel 2. Faktor luar berisi keterlibatan instansi dari luar (eksternal) dalam proses pembebasan tanah, yaitu Badan Pertanahan Nasional (BPN) yang menghambat proses pembebasan tanah. Variabel-variabel dalam faktor ini disajikan dalam Tabel 3. 
Tabel 1. Variabel faktor tahapan dan teknis pelaksanaan pengadaan tanah

\begin{tabular}{|c|c|c|c|}
\hline No & Variabel & Uraian kegiatan & Referensi \\
\hline 1 & $\mathrm{X} 1$ & Penyusunan dokumen perencanaan pengadaan tanah & $\mathrm{U}$ \\
\hline 2 & $\mathrm{X} 2$ & Pemberitahuan rencana pembangunan & $\mathrm{U}$ \\
\hline 3 & $\mathrm{X} 3$ & Pendataan awal lokasi rencana pembangunan & $\mathrm{U}$ \\
\hline 4 & $\mathrm{X} 4$ & Konsultasi publik rencana pembangunan & $\mathrm{U}$ \\
\hline 5 & $\mathrm{X} 5$ & $\begin{array}{l}\text { Inventarisasi dan identifikasi penguasaan, pemilikan, penggunaan, dan } \\
\text { pemanfaatan tanah }\end{array}$ & $\mathrm{U} / \mathrm{P}$ \\
\hline 6 & X6 & Penetapan penilai & $\mathrm{U} / \mathrm{P}$ \\
\hline 7 & $\mathrm{X} 7$ & Musyawarah penetapan ganti kerugian & $\mathrm{U} / \mathrm{P}$ \\
\hline 8 & $\mathrm{X} 8$ & Pemberian ganti kerugian & $\mathrm{U} / \mathrm{P}$ \\
\hline 9 & X9 & Pemberian ganti kerugian dalam keadaan khusus & $\mathrm{P}$ \\
\hline 10 & $\mathrm{X} 10$ & Penitipan ganti kerugian & $\mathrm{P}$ \\
\hline 11 & $\mathrm{X} 11$ & Pelepasan objek pengadaan tanah & $\mathrm{U} / \mathrm{P}$ \\
\hline 12 & $\mathrm{X} 12$ & $\begin{array}{l}\text { Pemutusan hubungan hukum antara pihak yang berhak dengan objek } \\
\text { pengadaan tanah }\end{array}$ & $\mathrm{P}$ \\
\hline 13 & $\mathrm{X} 13$ & $\begin{array}{l}\text { Pendokumentasian peta bidang, daftar nominatif dan data administrasi } \\
\text { pengadaan tanah }\end{array}$ & $\mathrm{P}$ \\
\hline 14 & $\mathrm{X} 14$ & Penyerahan hasil pengadaan tanah & $\mathrm{U}$ \\
\hline $\begin{array}{l}\text { Keter } \\
U \\
P \\
P\end{array}$ & ngan: & $\begin{array}{l}g \text { Republik Indonesia Nomor } 2 \text { Tahun } 2012 \text { tentang Pengadaan Tanah bagi Pembangu } \\
\text { num. }\end{array}$ & \\
\hline
\end{tabular}

Tabel 2. Variabel faktor dalam

\begin{tabular}{|c|c|c|c|}
\hline No & Variabel & Uraian kegiatan & Referensi \\
\hline 1 & $\mathrm{X} 15$ & Pendanaan pengadaan tanah untuk kepentingan umum bersumber APBN & $\mathrm{U}$ \\
\hline 2 & $\mathrm{X} 16$ & Keterlambatan pembayaran Uang Ganti Kerugian (UGK) & $\mathrm{W}$ \\
\hline 3 & $\mathrm{X} 17$ & Pengumpulan data status tanah dan dokumennya & $\mathrm{P}$ \\
\hline 4 & $\mathrm{X} 18$ & Koordinasi pelaksana pengadaan tanah & $\mathrm{P}$ \\
\hline 5 & X19 & Penyimpanan, pendokumentasian, dan pengarsipan data pengadaan tanah & $\mathrm{P}$ \\
\hline 6 & $\mathrm{X} 20$ & $\begin{array}{l}\text { Verifikasi dan perbaikan terhadap peta bidang tanah dan/atau daftar } \\
\text { nominatif oleh Ketua Pelaksana Pengadaan Tanah apabila terdapat keberatan } \\
\text { atas hasil inventarisasi dan identifikasi }\end{array}$ & $\mathrm{P}$ \\
\hline 7 & $\mathrm{X} 21$ & Verifikasi oleh pelaksana pengadaan tanah bila terdapat masalah tanah sisa & $\mathrm{P}$ \\
\hline 8 & $\mathrm{X} 22$ & $\begin{array}{l}\text { Efisiensi, efektivitas, kondisi geografis dan sumber daya manusia dalam } \\
\text { penugasan Kepala Kantor Pertanahan sebagai Ketua Pelaksana Pengadaan } \\
\text { Tanah }\end{array}$ & $\mathrm{P}$ \\
\hline 9 & $\mathrm{X} 23$ & Tingkat kesulitan dalam menentukan nilai pembebasan tanah & $\mathrm{W}$ \\
\hline \multicolumn{4}{|c|}{$\begin{aligned} U= & \text { Undang-Undang Republik Indonesia Nomor } 2 \text { Tahun } 2012 \text { tentang Pengadaan Tanah bagi Pembangunan untuk } \\
& \text { Kepentingan Umum. }\end{aligned}$} \\
\hline$P$ & \multicolumn{3}{|c|}{$\begin{aligned}= & \text { Peraturan Kepala Badan Pertanahan Nasional Republik Indonesia Nomor } 5 \text { Tahun } 2012 \text { tentang Petunjuk Teknis } \\
& \text { Pelaksanaan Pengadaan Tanah. }\end{aligned}$} \\
\hline
\end{tabular}

Pembebasan tanah untuk jalan tol Cinere-Jagorawi seksi II B seharusnya selesai pada tahun 2010, tetapi hingga saat ini (status 15 Juni 2017) dari kebutuhan 17,6 ha baru bebas 16,1353 ha atau $91,677 \%$. Bidang tanah yang belum bebas sejumlah 33 bidang dengan luas bidang $1.464 \mathrm{~m}^{2}$. Dengan progres pembebasan tanah tersebut, mengakibatkan deviasi pada progres konstruksi sebesar $-4,0415 \%$, yaitu pada 16 Juli 2017 progres konstruksi rencana sebesar $74,6149 \%$, sementara progres konstruksi realisasinya sebesar 70,5734\%.
Akibat deviasi progres konstruksi tersebut menyebabkan konstruksi jalan tol belum bisa beroperasi, karena produktivitas proyek berkaitan dengan rencana selesainya konstruksi.

Konstruksi direncanakan akan selesai setelah enam bulan dari selesainya proses pembebasan tanah. Oleh karena itu, penelitian ini perlu dianalisis lebih lanjut pengaruh pembebasan tanah terhadap kinerja waktu proyek pembangunan jalan tol CinereJagorawi seksi II B. 
Tabel 3. Variabel faktor luar

\begin{tabular}{|c|c|c|c|}
\hline No & Variabel & Uraian variabel & Referensi \\
\hline 1 & X24 & Kewajiban BPN untuk hadir di lapangan saat pembayaran UGK & $\mathrm{U}$ \\
\hline 2 & $\mathrm{X} 25$ & Ketelitian BPN saat pemeriksaan status kepemilikan tanah & $\mathrm{W}$ \\
\hline 3 & $\mathrm{X} 26$ & Keberadaan pemilik tanah yang tidak diketahui & $\mathrm{W}$ \\
\hline 4 & $\mathrm{X} 27$ & $\begin{array}{l}\text { Menurut pemilik tanah yang belum membebaskan tanahnya, harga yang } \\
\text { ditawarkan pemerintah terlalu rendah sehingga masih ada tanah yang } \\
\text { tertahan }\end{array}$ & $\mathrm{W}$ \\
\hline 5 & $\mathrm{X} 28$ & $\begin{array}{l}\text { Pemilik tanah menganggap ganti rugi untuk bangunan kecil, sampai saat } \\
\text { dilakukannya wawancara ada yang belum dibayar }\end{array}$ & $\mathrm{W}$ \\
\hline 6 & $\mathrm{X} 29$ & Pemilik tanah meminta UGK naik & $\mathrm{W}$ \\
\hline 7 & $\mathrm{X} 30$ & Pemahaman pemilik tanah akan prosedur pembayaran UGK & $\mathrm{W}$ \\
\hline 8 & $\mathrm{X} 31$ & $\begin{array}{l}\text { Adanya sengketa tanah/double sertifikat (kepemilikan tanah lebih dari } \\
\text { satu orang pada tanah yang sama) }\end{array}$ & $\mathrm{W}$ \\
\hline 9 & $\mathrm{X} 32$ & Masalah tanah sisa & $\mathrm{P}$ \\
\hline 10 & $\mathrm{X} 33$ & $\begin{array}{l}\text { Keterbatasan waktu bagi BPN dalam menangani kegiatan pengadaan } \\
\text { tanah karena banyaknya tanah yang harus dibebaskan (tidak hanya } \\
\text { menangani satu kasus pembebasan tanah) }\end{array}$ & $\mathrm{W}$ \\
\hline 11 & X34 & Koordinasi pejabat/petugas di lapangan & $\mathrm{W}$ \\
\hline 12 & $\mathrm{X} 35$ & $\begin{array}{l}\text { Lamanya proses sertifikasi tanah, sampai saat dilakukannya wawancara } \\
\text { belum ada yang sertifikasi }\end{array}$ & $\mathrm{W}$ \\
\hline 13 & X36 & $\begin{array}{l}\text { Pemantauan dan evaluasi terhadap penguasaan, pemilikan, penggunaan } \\
\text { dan pemanfaatan hasil pengadaan tanah bagi pembangunan untuk } \\
\text { kepentingan umum }\end{array}$ & $\mathrm{P}$ \\
\hline \multicolumn{4}{|c|}{$\begin{array}{l}\text { Keterangan: } \\
\begin{aligned} U= & \text { Undang-Undang Republik Indonesia Nomor } 2 \text { Tahun } 2012 \text { tentang Pengadaan Tanah bagi Pembangunan untuk Kepentingan } \\
P= & \text { Umum. } \\
& \text { Peraturan Kepala Badan Pertanahan Nasional Republik Indonesia Nomor } 5 \text { Tahun } 2012 \text { tentang Petunjuk Teknis Pelaksanaan }\end{aligned}\end{array}$} \\
\hline
\end{tabular}

\section{Metode}

Metode penelitian disajikan dalam flowchart pada Gambar 1. Penetapan variabel penelitian, berdasarkan hasil diskusi dengan pihak PT. Trans Lingkar Kita Jaya (TLKJ) didapat tiga variabel utama, yaitu: pendataan status kepemilikan atas tanah, kesepakatan harga, dan keterlambatan pembayaran UGK. Dari ketiga variabel utama tersebut dapat diidentifikasi satu variabel terikat (keterlambatan) dan 36 variabel bebas.

Kuesioner disusun dari variabel-variabel penelitian yang diberi ukuran pengaruh. Responden diminta untuk memberikan penilaian berdasarkan pengaruhnya. Kuesioner terdiri dari tiga bagian yaitu: tahapan dan teknis pelaksanaan pengadaan tanah, faktor dalam, faktor luar. Penyebaran kuesioner, penyebaran kuesioner kepada Pejabat Pembuat Komitmen (PPK) pengadaan tanah jalan tol Cinere-Jagorawi dan BPN Kota Depok, serta masyarakat. Kuesioner disebar pada minimal 30 responden sebagai syarat minimal data yang dibutuhkan untuk analisa statistik (Sadono, 2007).

Analisis regresi dengan menggunakan program SPSS. Dalam analisis telah diteliti hubungan antara variabel terikat keterlambatan dengan varibel bebas pembebasan tanah. Berdasarkan hasil diskusi dengan pihak PT. TLKJ didapat tiga variabel utama, yaitu pendataan status kepemilikan atas tanah, kesepakatan harga dan keterlambatan pembayaran UGK. Dari ketiga variabel utama tersebut dapat diidentifikasi satu variabel terikat (keterlambatan) dan tiga bagian kuesioner di atas.

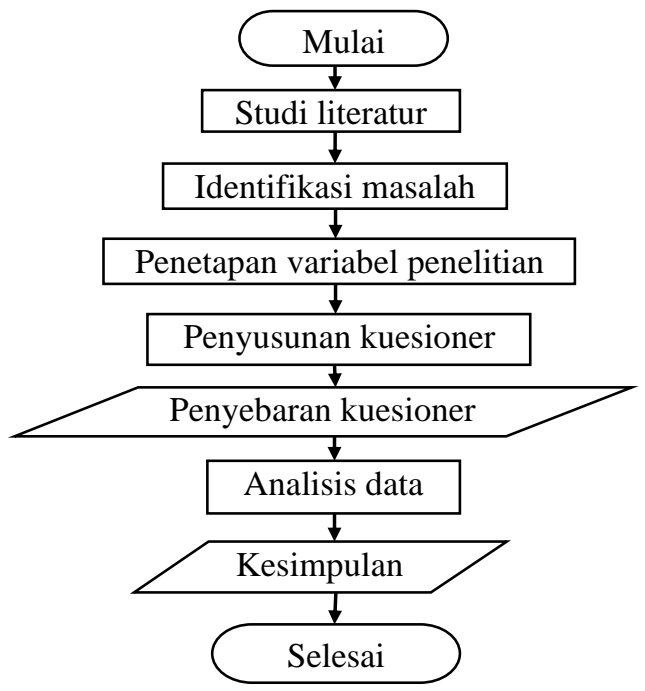

Gambar 1. Flowchart metode penelitian

Kesimpulan dari rumus regresi yang dihasilkan, dapat dilihat hubungan antara variabel terikat keterlambatan terhadap variabel bebas pembebasan tanah. Dari ketiga variabel utama hasil diskusi 
dengan pihak PT. TLKJ dapat diidentifaksi satu variabel terikat (keterlambatan) dan 36 variabel bebas. Flowchart untuk analisis statistik adalah pada Gambar 2.

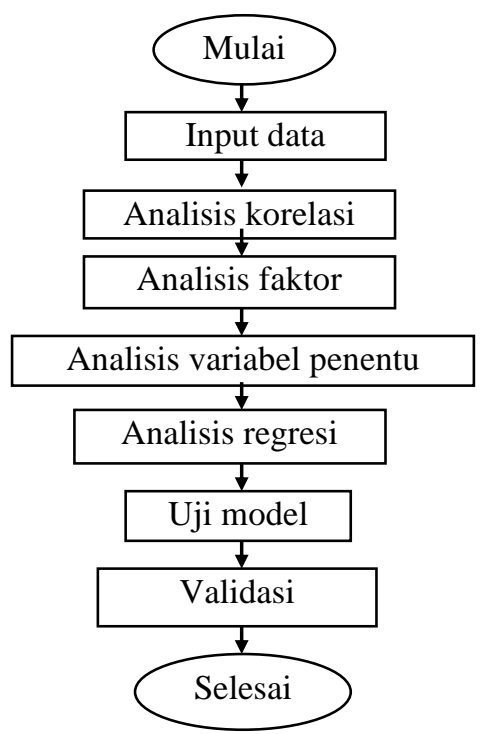
Gambar 2. Uji hubungan antara variabel bebas
dan variabel terikat

Analisis korelasi adalah suatu bentuk analisis data dalam penelitian yang bertujuan untuk mengetahui kekuatan atau bentuk arah hubungan di antara dua variabel atau lebih, dan besarnya pengaruh yang disebabkan oleh variabel bebas terhadap variabel terikat (Siregar, 2013). Metode yang digunakan dalam penelitian ini adalah metode korelasi Spearman.

Analisis faktor menemukan suatu cara meringkas (summarize) informasi yang ada dalam variabel asli (awal) menjadi satu set dimensi baru atau variate (factor atau component) (Ghozali, 2013). Sedangkan analisis variabel penentu, adalah analisis yang bertujuan untuk memilih variabel yang akan digunakan dalam model regresi.

Secara umum, analisis regresi adalah studi mengenai ketergantungan variabel terikat dengan satu atau lebih variabel bebas, untuk mengestimasi dan/atau memprediksi rata-rata populasi atau nilai rata-rata variabel terikat berdasarkan nilai variabel bebas yang diketahui. Hasil analisis regresi adalah berupa koefisien untuk masing-masing variabel bebas (Ghozali, 2013).

Uji model terdiri dari uji koefisien determinasi, untuk menguji ketepatan model regresi, uji pengaruh simultan ( $F$ test), digunakan untuk mengetahui apakah variabel independen secara bersama-sama atau simultan mempengaruhi variabel dependen, uji autokorelasi (Durbin Watson test), bertujuan menguji apakah dalam model regresi linear ada korelasi antara kesalahan pengganggu pada periode $\mathrm{t}$ dengan kesalahan pengganggu pada periode t-1 (sebelumnya). Jika terjadi korelasi, maka dinamakan ada problem autokorelasi (Ghozali, 2013).

Validasi dilakukan dengan mengkonfirmasi hasil penelitian untuk mengetahui pendapat atau tanggapan serta masukan terhadap hasil penelitian.

\section{Hasil dan Pembahasan}

\section{Analisis korelasi}

Analisis korelasi bertujuan untuk mengukur kekuatan asosiasi (hubungan) linear antara variabel terikat keterlambatan proyek pembangunan jalan tol dengan variabel bebas pembebasan tanah. Dari hasil analisis korelasi ini kemudian dipilih variabel-variabel yang berhubungan secara positif dan mempunyai nilai $r>0,300$. Variabel-variabel tersebut disajikan pada Tabel 4.

Tabel 4. Nilai korelasi spearman

\begin{tabular}{|c|c|c|c|}
\hline No. & Kode & Variabel & $\mathbf{R}$ \\
\hline 1 & $\mathrm{X} 4$ & Konsultasi publik rencana pembangunan & 0,575 \\
\hline 2 & X5 & $\begin{array}{l}\text { Inventarisasi dan identifikasi penguasaan, pemilikan, penggunaan, dan pemanfaatan } \\
\text { tanah }\end{array}$ & 0,652 \\
\hline 3 & $\mathrm{X} 12$ & Pemutusan hubungan hukum antara pihak yang berhak dengan objek pengadaan tanah & 0,615 \\
\hline 4 & $\mathrm{X} 15$ & Pendanaan pengadaan tanah untuk kepentingan umum bersumber dari APBN & 0,697 \\
\hline 5 & $\mathrm{X} 17$ & Pengumpulan data status tanah dan dokumennya & 0,617 \\
\hline 6 & $\mathrm{X} 22$ & $\begin{array}{l}\text { Efisiensi, efektivitas, kondisi geografis dan sumber daya manusia dalam penugasan } \\
\text { kepala kantor pertanahan sebagai ketua pelaksana pengadaan tanah }\end{array}$ & 0,708 \\
\hline 7 & $\mathrm{X} 23$ & Tingkat kesulitan dalam menentukan nilai pembebasan tanah & 0,697 \\
\hline 8 & X33 & $\begin{array}{l}\text { Keterbatasan waktu bagi BPN dalam menangani kegiatan pengadaan tanah karena } \\
\text { banyaknya tanah yang harus dibebaskan (tidak hanya menangani satu kasus } \\
\text { pembebasan tanah) }\end{array}$ & 0,572 \\
\hline
\end{tabular}


Tabel 5. Analisis faktor pembebasan tanah terhadap keterlambatan proyek pembangunan jalan tol

\begin{tabular}{|c|c|c|c|c|}
\hline Faktor & Kode & Variabel & $\begin{array}{c}\text { Koefisien } \\
\text { faktor }\end{array}$ & $\begin{array}{l}\text { Variabel } \\
\text { pengganti }\end{array}$ \\
\hline \multirow[t]{2}{*}{1} & $\mathrm{X} 15$ & $\begin{array}{l}\text { Pendanaan pengadaan tanah untuk kepentingan umum bersumber } \\
\text { dari APBN }\end{array}$ & 0,840 & \multirow[t]{2}{*}{ Pendanaan } \\
\hline & $\mathrm{X} 23$ & Tingkat kesulitan dalam menentukan nilai pembebasan tanah & 0,861 & \\
\hline \multirow{4}{*}{2} & $\mathrm{X} 4$ & Konsultasi publik rencana pembangunan & 0,713 & \multirow{4}{*}{ Persiapan } \\
\hline & $\mathrm{X} 5$ & $\begin{array}{l}\text { Inventarisasi dan identifikasi penguasaan, pemilikan, penggunaan, } \\
\text { dan pemanfaatan tanah }\end{array}$ & 0,788 & \\
\hline & $\mathrm{X} 12$ & $\begin{array}{l}\text { Pemutusan hubungan hukum antara pihak yang berhak dengan } \\
\text { objek pengadaan tanah }\end{array}$ & 0,729 & \\
\hline & $\mathrm{X} 17$ & Pengumpulan data status tanah dan dokumennya & 0,566 & \\
\hline 3 & $\mathrm{X} 33$ & $\begin{array}{l}\text { Efisiensi, efektivitas, kondisi geografis dan sumber daya manusia } \\
\text { dalam penugasan kepala kantor pertanahan sebagai ketua } \\
\text { pelaksana pengadaan tanah } \\
\text { Keterbatasan waktu bagi BPN dalam menangani kegiatan } \\
\text { pengadaan tanah karena banyaknya tanah yang harus dibebaskan } \\
\text { (tidak hanya menangani satu kasus pembebasan tanah) }\end{array}$ & 0,732 & $\begin{array}{c}\text { Pelaksana } \\
\text { pengadaan } \\
\text { tanah }\end{array}$ \\
\hline
\end{tabular}

Tabel 6. Analisis variabel penentu pembebasan tanah terhadap keterlambatan proyek pembangunan jalan tol

\begin{tabular}{ccl}
\hline Faktor Kode & \multicolumn{1}{c}{ Variabel } \\
\hline 1 & X15 & Pendanaan pengadaan tanah untuk kepentingan umum bersumber dari APBN \\
2 & X17 & Pengumpulan data status tanah dan dokumennya \\
3 & X33 & $\begin{array}{l}\text { Keterbatasan waktu bagi BPN dalam menangani kegiatan pengadaan tanah karena } \\
\text { banyaknya tanah yang harus dibebaskan (tidak hanya menangani satu kasus pembebasan } \\
\text { tanah) }\end{array}$ \\
\hline
\end{tabular}

\section{Analisis faktor}

Untuk menyederhanakan jumlah vaiabel yang mempunyai nilai $r>0,300$ dilakukan analisis faktor dengan metode Principal Component Analysis dan metode Rotasi Varimax. Tiap faktor mempunyai sekelompok variabel yang menggambarkan karakteristik umum dari faktor tersebut yang dapat dilihat pada Tabel 5 .

\section{Analisis variabel penentu}

Untuk memilih variabel yang akan digunakan dalam model regresi, dilakukan dengan analisis variabel penentu, dengan nilai $r$ yang paling rendah. Hasilnya adalah pada Tabel 6. Variabel penentu yang mewakili tiap faktor tersebut adalah variabel terbaik untuk digunakan dalam model regresi.

\section{Analisis regresi berganda linier}

Analisis regresi berganda digunakan untuk mengetahui pengaruh satu atau lebih variabel bebas (independent) terhadap satu variabel tak bebas (dependent) (Siregar, 2013). Analisis regresi berganda linier mengestimasi besarnya koefisienkoefisien yang dihasilkan oleh persamaan yang bersifat linier serta menggunakan variabel penentu yang telah didapat sebelumnya. Hasilnya adalah :

$$
Y=3,630+0,34 X 15+0,257 \times 17-0,146 \times 33
$$

Dimana Y adalah keterlambatan proyek pembangunan jalan tol, X15 adalah pendanaan pengadaan tanah untuk kepentingan umum bersumber dari APBN, X17 adalah Pengumpulan data status tanah dan dokumennya dan X33 adalah Keterbatasan waktu bagi ABPN dalam menangani kegiatan pengadaan tanah karena banyaknya tanah yang harus dibebaskan (tidak hanya menangani satu kasus pembebasan tanah).

\section{Analisis persamaan regresi:}

Nilai konstanta sebesar 3.630 artinya bahwa jika variabel independen pendanaan pengadaan tanah untuk kepentingan umum bersumber dari APBN (X15), Pengumpulan data status tanah dan dokumennya (X17), Keterbatasan waktu bagi BPN dalam menangani kegiatan pengadaan tanah karena banyaknya tanah yang harus dibebaskan (tidak hanya menangani satu kasus pembebasan tanah) (X33) dianggap konstan maka variabel dependen Keterlambatan proyek pembangunan jalan tol (Y) akan naik sebesar 3.630. 
Koefisien regresi Pendanaan pengadaan tanah untuk kepentingan umum bersumber dari APBN (X15) bertanda positif yang berarti memiliki hubungan searah. Hal ini berarti jika dana APBN lancar, maka pembebasan tanah akan berjalan dengan lancar sehingga proyek pembangunan jalan tol akan berjalan dengan lancar. Koefisien regresi Pengumpulan data status tanah dan dokumennya (X17) bertanda positif yang berarti memiliki hubungan searah. Hal ini berarti jika pengumpulan data status tanah dan dokumennya lengkap, maka pembebasan tanah akan berjalan dengan lancar, sehingga proyek pembangunan jalan tol akan berjalan dengan lancar. Koefisien regresi Keterbatasan waktu bagi BPN dalam menangani kegiatan pengadaan tanah karena banyaknya tanah yang harus dibebaskan (tidak hanya menangani satu kasus pembebasan tanah) (X33) bertanda negatif yang berarti memiliki hubungan berlawanan arah. Hal ini berarti jika waktu bagi BPN untuk menangani kegiatan pengadaan tanah jalan tol terbatas maka pembebasan tanah jalan tol berjalan lambat, sehingga proyek pembangunan jalan tol terlambat, dan jika waktu bagi BPN untuk menangani kegiatan pengadaan tanah jalan tol ditambah maka pembebasan tanah jalan tol berjalan cepat, sehingga proyek pembangunan jalan tol akan berjalan dengan lancar.

\section{Uji model}

Koefisien determinasi digunakan untuk menguji ketepatan model regresi (Ghozali, 2013). Besarnya nilai $\mathrm{R}^{2}$ adalah $82 \%$ yang berarti variabilitas variabel dependen yang dapat dijelaskan oleh variabilitas variabel independen sebesar $82 \%$. Sedangkan sisanya sebesar $18 \%$ dijelaskan oleh variabel yang tidak dimasukkan dalm model regresi. Jadi, model yang diperoleh baik.

Uji pengaruh simultan digunakan untuk mengetahui apakah variabel independen secara bersama-sama atau simultan mempengaruhi variabel dependen (Ghozali, 2013). Nilai F test sebesar 77,8 yang berarti variabel independen X15 (Pendanaan pengadaan tanah untuk kepentingan umum bersumber dari APBN, X17 (Pengumpulan data status tanah dan dokumennya), dan X33 (Keterbatasan waktu bagi BPN dalam menangani kegiatan pengadaan tanah karena banyaknya tanah yang harus dibebaskan (tidak hanya menangani satu kasus pembebasan tanah) secara simultan mempengaruhi variabel dependen $\mathrm{Y}$ (keterlambatan proyek pembangunan jalan tol).

Uji autokorelasi bertujuan untuk menguji apakah dalam model regresi linear ada autokorelasi atau tidak. Model regresi yang baik adalah regresi yang bebas dari autokorelasi (Ghozali, 2013). Untuk menguji ada atau tidaknya autokorelasi dalam model regresi digunakan batasan nilai $\mathrm{d}<2$ yang menunjukkan bahwa tidak adanya autokorelasi. Durbin Watson test menghasilkan nilai 1,397 yang artinya dalam model regresi tidak ada autokorelasi. Berdasarkan ketiga uji di atas, model regresi yang menunjukkan hubungan antara variabel bebas pembebasan tanah dengan variabel terikat keterlambatan Proyek Pembangunan Jalan Tol dinyatakan valid.

\section{Validasi pakar}

Setelah didapat model regresi yang menunjukkan hubungan antara variabel bebas Pembebasan Tanah dengan variabel terikat keterlambatan proyek pembangunan jalan tol, langkah selanjutnya adalah melakukan validasi model regresi tersebut kepada pakar. Validasi dilakukan dengan mengkonfirmasi hasil penelitian untuk mengetahui pendapat atau tanggapan serta masukan terhadap hasil penelitian. Hasil validasi dengan pakar adalah pada Tabel 7 .

\section{Kesimpulan}

Dari hasil analisis data dan model regresi yang dihasilkan dapat disimpulkan bahwa pembebasan tanah berpengaruh terhadap keterlambatan proyek pembangunan jalan tol, serta faktor pembebasan tanah yang paling berpengaruh terhadap keterlambatan proyek pembangunan jalan tol adalah pendanaan pengadaan tanah untuk kepentingan umum bersumber dari APBN dengan koefisien 0,34. Pengumpulan data status tanah dan dokumennya dengan koefisien 0,257. Keterbatasan waktu bagi BPN dalam menangani kegiatan pengadaan tanah karena banyaknya tanah yang harus dibebaskan (tidak hanya menangani satu kasus pembebasan tanah) dengan koefisien 0,146.

Tabel 7. Validasi pakar

\begin{tabular}{lccc}
\hline \multirow{2}{*}{ Nama pakar } & \multicolumn{3}{c}{ Faktor penentu } \\
\cline { 2 - 4 } & APBN & Pengumpulan status tanah & Keterbatasan waktu \\
\hline Agung Sapto B & $\checkmark$ & $\checkmark$ & $\checkmark$ \\
Medy Lelelangan & $\checkmark$ & $\checkmark$ & $\checkmark$ \\
Edi Suwardi & $\checkmark$ & $\checkmark$ & $\checkmark$ \\
Sunyoto & $\checkmark$ & $\checkmark$ & $\checkmark$ \\
\hline
\end{tabular}

Sumber: Hasil Wawancara, 2018 


\section{Saran}

Untuk selanjutnya, dalam pembebasan tanah perlu diperhatikan pemerintah harus menyediakan dana APBN untuk pembebasan tanah sebelum proyek mulai dikerjakan. Diharapkan proses pembebasan tanah secara keseluruhan selesai sebelum proyek dikerjakan. Pengumpulan data status tanah dan dokumen untuk pembebasan tanah jalan tol harus dilakukan dengan lengkap dan teliti. agar pembebasan tanah tidak mengalami kendala. Disediakan waktu yang lebih panjang untuk BPN dalam menangani kegiatan pengadaan tanah, karena banyaknya tanah yang harus dibebaskan.

\section{Ucapan Terima Kasih}

Pada kesempatan kali ini penulis ingin mengucapkan terimakasih kepada Bapak Agung Sapto B selaku Pejabat Pembuat Komitmen (PPK) Pengadaan Tanah jalan tol Cinere-Jagorawi, Bapak Medy Lelelangan selaku Kasi Pengadaan Tanah BPN Kota Depok, Bapak Edi Suwardi selaku Kasi Infrastruktur BPN Kota Depok. Bapak Sunyoto selaku Kasubsi Pemanfaatan Tanah Pemerintah dan Penilaian Tanah Kota Depok, Ibu Elis selaku Analis Kendali Mutu BPN Kota Depok, Kak Brilian Muhammad dan Kak Muwahidin Fadhol selaku PTT BPN Kota Depok, serta kepada masyarakat yang telah bersedia mengisi kuesioner.

\section{Daftar Pustaka}

Ade-Surya, T., \& Wirabrata, A. (2011). Masalah Kebijakan dalam Pengadaan Tanah untuk Pembangunan Infrastruktur, Jurnal Ekonomi dan Kebijakan Publik, 2(2), 729-751.

Dharmawan, Y. (2012). Dampak Ketidak Pastian Waktu Pembebasan Tanah terhadap Besaran Tarif Awal pada Proyek Investasi Jalan Tol, Tesis, Universitas Indonesia.

Firmanto, Z., Haryono, Wiguna P. A. (2010). Pengaruh Partisipasi Masyarakat dan Peran Serta Pemerintah dalam Proses Pembebasan Lahan untuk Proyek Pembangunan Jalan Tol di Surabaya (Studi Kasus Jalan Tol Waru-Bandara Juanda), dipresentasikan pada Seminar Nasional Manajemen Teknologi XI (B-9-1-B-9-9), Surabaya, Indonesia: Program Studi MMT, Institut Teknologi Sepuluh Nopember.

Ghozali, I. (2013). Aplikasi analisis multivariete dengan program IBM SPSS 23 (edisi 8). Semarang: Badan Penerbit Universitas Diponegoro.
Hasani, F. A., Kushardjoko, W., Purwanto, D., \& Rahmalia, A. (2016). Analisa Kelayakan Pembangunan Jalan Tol Pemalang Batang. Jurnal Karya Teknik Sipil, 5(1), 11-24.

Hermawan, F., Kristiani, F., \& Santoso, T. D. (2011). Pengaruh Pembebasan Lahan terhadap Risiko Proyek Konstruksi (Studi Kasus Social Engineering Proyek Jalan Tol Ruas Semarang Bawen). Jurnal Teknik, 32(2), 88-94.

Hutabarat, S. (2008). Kajian Pengadaan Lahan Pembangunan Jalan Studi Kasus: Flyover Amplas Medan, Tesis, Universitas Sumatera Utara.

Kamaruzzaman, F. (2012). Studi Keterlambatan Penyelesaian Proyek Konstruksi. Jurnal Teknik Sipil Untan, 12(2), 175-190.

Listyaningsih, D., \& Utomo, C. (2014). Pengaruh Keterlambatan Pembebasan Lahan terhadap Keputusan Investasi Proyek Jalan Tol SurabayaMojokerto. Jurnal Teknik Pomits, 3(2), E-43-E-46.

Marlijanto, S. D. (2010). Konsinyasi Ganti Rugi dalam Pengadaan Tanah untuk Kepentingan Umum (Studi Pengadaan Tanah untuk Pembangunan Proyek Jalan Tol Semarang-Solo di Kabupaten Semarang), Tesis, Universitas Diponegoro.

Mekanisari, N. (2009). Identifikasi Faktor Risiko Proses Pembebasan Tanah dalam Upaya Meningkatkan Kinerja Waktu pada Proyek Banjir Kanal Timur DKI Jakarta, Tesis, Universitas Indonesia.

Musra, A. (2014). Faktor-Faktor Penentu Keterlambatan Pembangunan Jalan Lingkar Utara Kota Solok. Jurnal Pembangunan Wilayah dan Kota, 10(1), 70-82.

Sadono, S. (2007). Faktor-Faktor yang Menghambat Pelaksanaan Pengadaan Tanah terhadap Kinerja Waktu Proyek Pembangunan Jalan Tol, Tesis, Universitas Indonesia.

Santoso, N. B., Mochamad Solikin, S. T., \& Sahid, I. M. N. (2017). Analisis manajemen risiko pada proyek pembangunan jalan tol (studi kasus proyek pembangunan jalan tol solo-ngawi-kertosono ruas ngawi-kertosono paket 3), Doctoral dissertation, Universitas Muhammadiyah Surakarta).

Siregar, S. (2013). Metode penelitian kuantitatif : dilengkapi dengan perbandingan perhitungan manual \& SPSS (Edisi 1). Jakarta: Kencana. 